\title{
Diagnóstico e genotipagem do vírus da pseudoraiva por nested-PCR e análise de restrição enzimática
}

\author{
Diagnosis and genotyping of pseudorabies virus by nested-PCR and restriction enzyme analysis
}

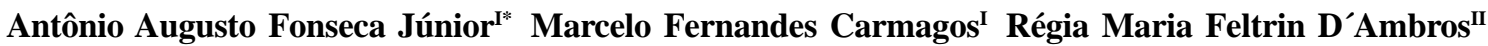 \\ Alexandre Carvalho Braga'II Janice Ciacci-Zanella ${ }^{\text {IV }}$ Marcos Bryana Heinemann $^{\text {V }}$ \\ Rômulo Cerqueira Leite ${ }^{\mathrm{v}}$ Jenner Karlisson Pimenta dos Reis ${ }^{\mathrm{V}}$
}

RESUMO

A pseudoraiva (PR) é uma enfermidade viral responsável por consideráveis perdas econômicas na indústria de suínos. O vírus da pseudoraiva (PrV) apresenta apenas um sorotipo, mas, por análise de restrição enzimática, foi classificado em quatro genótipos denominados I, II, III e IV. Os métodos usados para genotipagem dependem do isolamento do vírus, da purificação do DNA viral, da restrição enzimática do genoma completo e da visualização após eletroforese. $O$ objetivo deste trabalho foi estabelecer um método mais rápido e sensível para detectar e genotipar o PrV por nested-PCR e análise de restrição enzimática. Vinte isolados do $\operatorname{PrV}$ das regiões Sul e Sudeste do Brasil e a estirpe padrão Shope foram replicadas em células $P K-15$ e submetidas à nested-PCR para o gene da glicoproteína E. Além desses vírus previamente isolados, foram avaliadas 75 amostras clínicas de cérebro de suíno em um total de 25 animais positivos para a $P R$ no isolamento e na soroneutralização viral e 50 amostras negativas provenientes de animais negativos na soroneutralização viral e de granjas sem histórico de PR. Todas as amostras clínicas tiveram resultados compatíveis com o isolamento e a soroneutralização, e a totalidade das amostras positivas foi classificada como genótipo II. A sensibilidade analítica da nested-PCR foi de $10^{-1,3} \mathrm{TCID}_{50} \mathrm{~mL}^{-1}$. A combinação da nestedPCR e da restrição enzimática foi capaz de detectar e genotipar o vírus com resultados em um a dois dias, sendo mais rápida que os métodos convencionais de restrição do genoma completo que podem demorar até sete dias.

Palavras-chave: genotipagem, nested-PCR, pseudoraiva restrição enzimática.

\begin{abstract}
Pseudorabies is a disease caused by Suid herpesvirus 1 (PrV) and is responsible for considerable economic losses in the swine industry. The PrV has only one serotype, but based on RFLP (restriction fragment length polymorphism) the virus was divided into four genotypes named I, II, III, IV. The classical methods for PrV genotyping usually require virus isolation, DNA purification enzyme restriction analysis and a long electrophoresis. The aim of this research was to describe a faster and more sensitive method to detect and genotype PrV based on nested-PCR and restriction enzyme analysis. Twenty $\operatorname{PrV}$ isolates from south and southeast regions of Brazil, and the standard strain Shope were grown in PK-15 cells and submitted to PCR for glycoprotein E gene amplification. Additionally were tested 75 clinical samples (swine brain), with 25 positives for virus isolation and seroneutralization, and 50 negatives from a flock free $P R$ with negative results in seroneutralization test. There was $100 \%$ of agreement between results of nested-PCR and virus isolation and seroneutralization and all samples detected were classified as genotype II. The nested-PCR, combined with restriction enzyme analysis, was able to detect and genotype PrV in 1-2 days with a sensitivity of $10^{-1,3} \mathrm{TCID}_{50} \mathrm{~mL}^{-1}$. It was faster than classical methods described in the literature that require at least 7 days to be completed.
\end{abstract}

Key words: genotype, nested-PCR, pseudorabies, restriction enzyme analysis.

\footnotetext{
'Laboratório Nacional Agropecuário, MAPA. Av. Rômulo Joviano, sn, CP 50, 33600-000, Pedro Leopoldo, MG, Brasil. E-mail: augustofj@yahoo.com.br. *Autor para correspondência.

IIInstituto de Pesquisas Veterinárias Desidério Finamor (IPVDF), Fepagro, Eldorado do Sul, RS, Brasil.

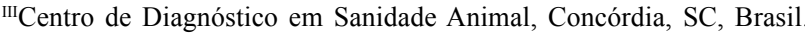

${ }^{\mathrm{IV}}$ Laboratório de Sanidade, EMBRAPA Suínos e Aves, Concórdia, SC, Brasil

'Laboratório de Retroviroses, Escola de Veterinária, UFMG, Belo Horizonte, MG, Brasil.
} 


\section{INTRODUÇÃO}

A pseudoraiva (PR) é uma enfermidade de grande importância na suinocultura em razão de elevados prejuízos que causa na cadeia produtiva da indústria suína, seja por danos diretos nas granjas, seja também por barreiras sanitárias. O agente etiológico da enfermidade é o vírus da pseudoraiva (PrV), também denominado herpesvírus suíno 1 , um membro da família Herpesviridae, subfamília Alphaherpesvirinae, que possui apenas um sorotipo (MURPHY et al., 1995). A transmissão do vírus geralmente ocorre por via oronasal. O suíno é o hospedeiro natural do PrV, mas o vírus pode infectar outros animais domésticos como cães e bovinos. A intensidade dos sinais clínicos e a mortalidade dependem da idade do hospedeiro, e a infecção latente é sempre estabelecida após a recuperação do animal (METTENLEITER et al., 1999).

Apesar de o vírus possuir apenas um sorotipo, diferentes genótipos do PrV podem ser identificados pela análise por endonucleases de restrição, e a identificação dos genótipos é importante para estudos epidemiológicos (KLUGE et al., 1999). O método baseado em análise de polimorfismos de fragmentos de restrição (RFLP) com a enzima BamHI foi descrito previamente e provou ser capaz de dividir o PrV em quatro genótipos. Os genótipos I e II estão distribuídos mundialmente, e os genótipos III e IV estiveram restritos à Dinamarca e Tailândia, respectivamente, e não foram mais relatados (CHRISTENSEN, 1995).

No Brasil, foram identificados os genótipos I e II, por meio do RFLP (PIATTI et al., 2001; SCHAEFFER et al., 2006). O Rio Grande do Sul (RS) manteve-se sem relato da PR durante 49 anos, até o foco de 2003, causado por um vírus pertencente ao genótipo II. Análises de RFLP permitiram detectar que este era o mesmo tipo genômico presente no Estado de Santa Catarina, que ainda não havia completado seu programa de erradicação na época do surto no RS (SILVA et al., 2005). O mesmo método identificou amostras do genótipo I no Estado do Paraná, um tipo incomum no Brasil, mas presente na Argentina, o que indica a possível introdução desse genótipo por animais com o vírus latente daquele país (SCHAEFER et al., 2006).

O método de análise por restrição enzimática de genoma completo com BamHI é útil na diferenciação do PrV, mas muito complexo, pois requer isolamento do vírus, processos de ultracentrifugação para purificação do DNA e eletroforese de temperatura controlada que pode durar até 20 horas. Além da boa qualidade da amostra para evitar contaminações e destruição do vírus, é necessário que este esteja ativo, já que o PrV não pode ser isolado quando se encontra em latência (POMERANZ et al., 2005).

A detecção do vírus, no estado latente ou replicativo, pela PCR, é uma ferramenta importante no controle da doença (YOON et al., 2005; YOON et al., 2006; SÁMI et al., 2007). Essa metodologia foi sugerida no plano de erradicação da PR no Brasil elaborado pelo Ministério da Agricultura, Pecuária e Abastecimento (BRASIL, 2007) e recomendada pela Organização Mundial de Saúde Animal (OIE, 2008).

O objetivo deste trabalho foi associar as técnicas de nested-PCR e a análise de restrição enzimática, visando à obtenção de um método rápido e sensível para detecção e caracterização genotípica do PrV.

\section{MATERIAL E MÉTODOS}

Amostras

Vinte amostras do PrV isoladas nas Regiões Sul e Sudeste do Brasil previamente genotipadas (PIATTI et al., 2001; SILVA et al., 2005) e a estirpe padrão Shope foram multiplicadas em células PK-15 (Tabela 1). A estirpe padrão Shope, genótipo I, foi utilizada como controle positivo em todos os testes descritos neste trabalho. O DNA total foi extraído por meio do kit comercial Wizard ${ }^{\circledR}$ Genomic DNA Purification (Promega, EUA) e armazenado a $-20^{\circ} \mathrm{C}$, para utilização na nested-PCR e genotipagem. Amostras do genótipo III e IV não foram utilizadas por terem sido descritas exclusivamente na Dinamarca, onde a PR já foi erradicada, e na Tailândia, também livre de novos focos com esses genótipos nos últimos anos (CHRISTENSEN, 1995).

Além das amostras de vírus isolados já genotipados, 75 amostras de cérebro de suíno foram utilizadas para avaliação da nested-PCR em material clínico. Vinte e cinco dessas amostras eram provenientes de focos de PR e outras 50 amostras foram colhidas de animais abatidos em frigorífico e provenientes de granjas sem histórico de PR. Todas as amostras positivas foram submetidas previamente ao isolamento viral e à soroneutralização viral segundo método descrito pela OIE (2008). As amostras negativas foram submetidas apenas à soroneutralização.

Análise in silico dos sítios de restrição enzimática

A restrição enzimática para o gene codificante da glicoproteína $\mathrm{E}$ foi baseada nas sequências obtidas por FONSECA JR. et al. (2009), que foram submetidas ao programa pDraw32 (KJELD, 2006), para a escolha de uma enzima de restrição que clivasse os amplicons e diferenciasse os genótipos. Os 
Tabela 1 - Amostras-padrão e de isolados brasileiros de PrV utilizadas no estudo.

\begin{tabular}{|c|c|c|c|c|c|}
\hline Vírus & Isolado de & Origem & Características & Ano de isolamento & Genótipo \\
\hline Shope & Bovino & ATCC; Hungria & Padrão & 1942 & I \\
\hline Nova Prata & Bovino & $\mathrm{RS}$ & Isolado & 1956 & II \\
\hline 031 & Suíno & Coronel Vívida - PR* & Isolado & 1984 & I \\
\hline 673 & Suíno & M. Cândido Rondon - PR & Isolado & 1984 & I \\
\hline 936 & Suíno & Santa Rosa $-\mathrm{PR}^{*}$ & Isolado & 1983 & I \\
\hline Piau & Suíno & Igarapé - MG & Isolado & 1984 & I \\
\hline 3288 & Suíno & Seara - SC & Isolado & 2002 & II \\
\hline 3293 & Suíno & Xanxerê - SC & Isolado & 1983 & II \\
\hline 3303 & Suíno & Toledo - PR & Isolado & 1984 & I \\
\hline 3308 & Suíno & Rio do Sul - SC & Isolado & 1989 & II \\
\hline 3333 & Suíno & Desconhecido - SC & Isolado & 2002 & II \\
\hline 3338 & Suíno & Ipumirim - SC & Isolado & 1983 & II \\
\hline 3380 & Suíno & Concórdia - SC & Isolado & 1986 & II \\
\hline 3356 & Suíno & Concórdia - SC & Isolado & 1988 & II \\
\hline 3370 & Suíno & Concórdia - SC & Isolado & 1984 & II \\
\hline 3319 & Suíno & Concórdia - SC & Isolado & 1989 & II \\
\hline EVI-192/03 & Suíno & Ponte Preta - RS & Isolado & 2003 & II \\
\hline EVI-193/03 & Suíno & Erechim - RS & Isolado & 2003 & II \\
\hline EVI-011/03 & Suíno & Pinheirinho do Vale - RS & Isolado & 2003 & II \\
\hline
\end{tabular}

*Refere-se ao Estado do Paraná.

iniciadores desenhados com o intuito de flanquear a região do polimorfismo e a enzima BtgI foram escolhidos para a utilização na nested-PCR seguida da restrição enzimática. A enzima $H p h I$ foi selecionada no mesmo programa para ser o controle da restrição enzimática para garantir que a reação de digestão não sofria inibição.

\section{Nested-PCR}

Os iniciadores externos gE-E-F (5'CCAACGACACGGGCCTCTAC-3') e gE-E-R (5'CGAGCGTGTAGTCCCAGGTG-3') e internos gE-I-R (5'-GCGTTCGTGTGCACCTCCT-3') e gE-I-F (GGGGACACGTTCGACCTGAT) foram desenhados com o auxílio do do programa Primer3 (ROZEN \& SKALETSKY, 1998). A nested-PCR foi realizada nas seguintes condições: a primeira reação de $20 \mu \mathrm{L}$ continha cinco pmoles de cada iniciador (gE-E-F e gEE-R), 1.5U de Taq polimerase (GoTaq, Promega, Estados Unidos), tampão GoTaq 5x, $\mathrm{MgCl} 1.9 \mathrm{mmol} \mathrm{L}^{-1}, 4 \%$ DMSO e DNTP a $200 \mu \mathrm{mol} \mathrm{L}^{-1}$ e $2 \mu \mathrm{L}^{2}$ de DNA. Os ciclos da reação foram os seguintes: desnaturação a $95^{\circ} \mathrm{C}$ por cinco minutos, 35 ciclos de $95^{\circ} \mathrm{C}$ por $50 \mathrm{~s}, 58^{\circ} \mathrm{C}$ por $40 \mathrm{~s}$, $72^{\circ} \mathrm{C}$ por 50 s e extensão a $72^{\circ} \mathrm{C}$, por cinco minutos. A segunda reação foi realizada como a seguir: iniciadores gE-I-F e gE-I-R e soluções de $20 \mu \mathrm{L}$ com 6 pmoles de cada iniciador, 1.0U de Taq polimerase (GoTaq), Tampão GoTaq 5x, 1.5 mmol L-1 $\mathrm{MgCl}_{2}, 4$ \% DMSO, 200 ( $\mathrm{mol} \mathrm{L}^{-1}$
DNTP e $2 \mu \mathrm{L}$ da reação externa. As temperaturas e os tempos da reação foram: $95^{\circ} \mathrm{C}$ por cinco minutos, 15 ciclos de $95^{\circ} \mathrm{C}$ por $40 \mathrm{~s}, 64^{\circ} \mathrm{C}$ por $40 \mathrm{~s}, 72^{\circ} \mathrm{C}$ por $40 \mathrm{~s}, 20$ ciclos de $95^{\circ} \mathrm{C}$ por $40 \mathrm{~s}, 59^{\circ} \mathrm{C}$ por $40 \mathrm{~s}, 72^{\circ} \mathrm{C}$ por $40 \mathrm{~s} \mathrm{e}$ extensão a $72^{\circ} \mathrm{C}$, por três minutos. $\mathrm{O}$ fragmento amplificado esperado de $317 \mathrm{pb}$ foi visualizado em gel de agarose a $1,5 \%$ e corado com brometo de etídeo $\left(0,5 \mu \mathrm{g} \mathrm{mL}^{-1}\right)$, sob luz ultravioleta.

Especificidade analítica

Amostras dos genótipos I e II de PrV (Tabela 1), amostra vacinal Bartha, herpesvírus bovino 1 (devido à proximidade filogenética) e de Streptococcus suis foram utilizadas para o teste de especificidade. $\mathrm{O}$ DNA dessas amostras foi extraído pelo mesmo método descrito anteriormente.

\section{Sensibilidade analítica}

Uma suspensão do isolado de campo F3303 $\left(10^{5,3} \mathrm{TCID}_{50} \mathrm{~mL}^{-1}\right)$ foi diluída em série, na base 10 até $10^{-7}$. Cada diluição foi utilizada para contaminar 10 amostras de cérebro de suínos negativos na sorologia e provenientes de uma granja sem histórico de PR. O DNA dessas amostras contaminadas foi extraído como citado anteriormente. A diluição com 10 resultados positivos foi repetida 21 vezes para a determinação da sensibilidade analítica, com nível de confiança de $95 \%$ (CAULCUTT \& BODDY, 1983). 
Amostras clínicas

A nested-PCR foi utilizada nas 75 amostras de cérebro de suíno descritas anteriormente para confirmação da sensibilidade e especificidade analítica do teste, como sugerido por ESPY et al. (2006), permitindo a verificação dos resultados positivos e negativos, bem como de reações inespecíficas. O teste de precisão da análise foi realizado com a repetição por 10 dias de uma amostra positiva, uma amostra contaminada no limite de detecção e uma amostra negativa. Os resultados foram analisados pelo teste Kappa (GART \& BUCK, 1966).

\section{Restrição enzimática}

Os produtos internos da amplificação do gene da glicoproteína E obtidos na nested-PCR (317 $\mathrm{pb}$ ) foram digeridos com a enzima de restrição BtgI, de acordo com as instruções do fabricante (New England, EUA). Todos os amplicons também foram submetidos à outra reação de restrição com HphI (New England, EUA). A amostra padrão Shope foi utilizada como controle positivo para se verificar o corte dos amplicons derivados dos isolados do genótipo I. O DNA digerido foi fracionado por eletroforese, em gel de agarose a $1,5 \%$, corado com brometo de etídeo $\left(0,5 \mu \mathrm{g} \mathrm{mL} \mathrm{m}^{-1}\right)$ e visualizado sob luz ultravioleta.

Comparação da nested-PCR com PCR convencional A comparação entre a nested-PCR e a PCR convencional descrita por BASCUÑANA et al. (1997) foi realizada a partir de amostras negativas contaminadas com diluições da amostra viral F3303 no mesmo processo definido no item Sensibilidade Analítica. A mistura para a reação foi constituída de: 7,5 pmoles de cada iniciador (gBI GAACCTGACGCTGCTGGAGGACCGACCG e gBIIAGGCCCTGGAAGAAGTGGCGATGCATGC), 1.5U de Taq polimerase (GoTaq, Promega, EUA), Tampão GoTaq $5 \mathrm{x}, \mathrm{MgCl}_{2} 1.5 \mathrm{mmol} \mathrm{L}^{-1}, 4 \%$ de DMSO, DNTP $200 \mu \mathrm{mol} \mathrm{L}^{-1}$, $2 \mu \mathrm{L}$ de DNA. Os ciclos da reação foram os seguintes: desnaturação a $95^{\circ} \mathrm{C}$ por cinco minutos, 35 ciclos de $95^{\circ} \mathrm{C}$ por $40 \mathrm{~s}, 59^{\circ} \mathrm{C}$ por $40 \mathrm{~s}, 72^{\circ} \mathrm{C}$ por $40 \mathrm{~s}$ e extensão a $72^{\circ} \mathrm{C}$ por cinco minutos.

\section{RESULTADOS}

A nested-PCR descrita teve sensibilidade analítica de $10^{-1,3} \mathrm{TCID}_{50} \mathrm{~mL}^{-1}$ correspondente ao menor título que obteve 10 reações positivas e sucesso nas 21 repetições. Na comparação com a PCR convencional, a nested-PCR foi 100 vezes mais sensível (Tabela 2 ). Todas as amostras de PrV foram amplificadas pela nested-PCR, exceto a amostra vacinal Bartha, por ser
Tabela 2 - Comparação da sensibilidade analítica da nested-PCR e PCR convencional para PrV.

\begin{tabular}{cccc}
\hline & \multicolumn{3}{c}{ Número de amostras positivas } \\
$\begin{array}{c}\text { Concentração } \\
\left(\text { TCID }_{\left.50 \mathrm{~mL}^{-1}\right)}\right.\end{array}$ & $\begin{array}{c}\text { Número de } \\
\text { repetições }\end{array}$ & Nested PCR & PCR gB* \\
\hline $10^{4,3}$ & 10 & 10 & 10 \\
$10^{3,3}$ & 10 & 10 & 10 \\
$10^{2,3}$ & 10 & 10 & 10 \\
$10^{1,3}$ & 10 & 10 & 10 \\
$10^{0,3}$ & 10 & 10 & 8 \\
$10^{-1,3}$ & 10 & 10 & 2 \\
$10^{-2,3}$ & 10 & 3 & 0 \\
\hline
\end{tabular}

* PCR descrita por BASCUÑANA et al., 1997.

deletada para o gene da glicoproteína E. Não houve amplificação inespecífica quando foi utilizada amostra do DNA de herpesvírus bovino. Também não houve amplificação para amostras de $\boldsymbol{S}$. suis, agente causador de uma doença neurológica semelhante à PR.

O teste de verificação da acurácia da nestedPCR teve resultados compatíveis com os obtidos no isolamento viral e a soroneutralização viral em amostras clínicas com um valor de Kappa igual a 1,0, nível de confiança de $95 \%$, significando concordância de $100 \%$ entre os testes. Todas as amostras positivas pela nested-PCR foram identificadas como pertencentes ao genótipo II. Não houve amplificação do fragmento de $\mathrm{gE}$ ou formação de bandas inespecíficas nas 50 amostras negativas testadas.

Polimorfismos de nucleotídeo único foram detectados nos genótipos I e II. A enzima BtgI, selecionada na análise computacional das sequências, teve sua eficiência confirmada nos testes de laboratório com duas bandas formadas para o genótipo I (uma banda com $217 \mathrm{pb}$ e outra com 100pb) e apenas uma banda de $317 \mathrm{pb}$ para o genótipo II. A enzima $\mathrm{HphI}$ clivou os produtos da nested-PCR de ambos os genótipos em fragmentos de 54, 129 e $134 \mathrm{pb}$. O fragmento menor não foi detectado no gel, e os dois últimos apareceram como apenas um em razão da semelhança nos tamanhos (Figura 1).

\section{DISCUSSÃO}

A rápida detecção e a caracterização de agentes infecciosos são essenciais para os programas de defesa sanitária animal. Uma doença como a PR, listada pela OIE, pode causar grandes impactos nas granjas acometidas, assim como gerar barreiras sanitárias relevantes para a suinocultura. O tempo gasto para realização do teste descrito neste trabalho foi de 


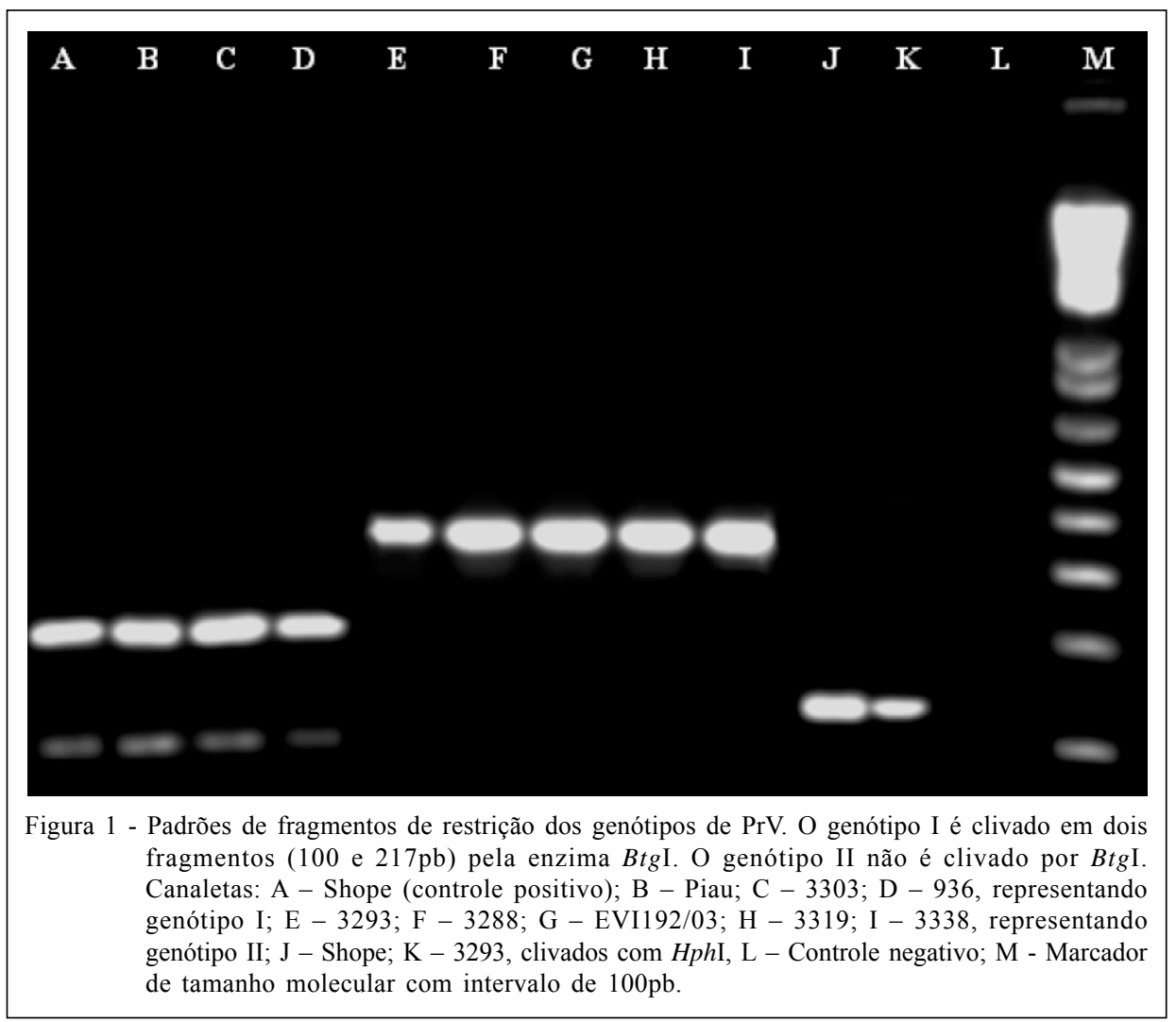

no máximo dois dias, bem inferior aos métodos descritos anteriormente, que podiam levar até sete dias entre o isolamento viral e a eletroforese (PIATTI et el., 2001; SCHAEFFER et al., 2006). A enzima selecionada clivou seletivamente o polimorfismo encontrado nas análises de bioinformática, permitindo diferenciar os genótipos virais I e II com precisão. A nested-PCR foi 100 vezes mais sensível do que uma PCR convencional descrita na literatura (BASCUÑANA et al. (1997).

A caracterização genotípica do $\operatorname{PrV}$ por análise de restrição enzimática foi utilizada por vários autores em estudos epidemiológicos, sendo o método baseado na restrição do genoma completo do PrV com BamHI, com variações no método de purificação do DNA viral, o mais utilizado (CHRISTENSEN, 1987; CHRISTENSEN, 1988; NISHIMORI et al., 1987, YAMADA et al., 1992; CHRISTENSEN, 1995; PIATTI et al., 2001; SILVA et al., 2005; SCHAEFER et al., 2006). Isolados de campo foram identificados por esse mesmo método como derivados de amostras vacinais na Polônia e Hungria (CHRISTENSEN et al., 1992). Isolados britânicos foram discriminados por amplificação de um fragmento longo do gene da glicoproteína $\mathrm{D}$ e posterior digestão por BamHI (BANKS, 1993). Em outro estudo, um algoritmo quantitativo foi desenvolvido para estimar a similaridade de isolados e amostras vacinais a partir das bandas geradas no gel após restrição enzimática do DNA viral (WEIGEL \& SCHERBA, 1997). Os métodos de sequenciamento, apesar de serem mais acessíveis, possuem custo relativamente alto quando comparado à digestão enzimática, além de serem tecnicamente mais elaborados. Além disso, no caso de vírus muito conservados, como os herpesvírus, podem não oferecer mais do que dois grandes grupos em suas árvores filogenéticas se as amostras forem muito próximas (GOLDBERG et al., 2003). A combinação da nested-PCR com a restrição enzimática é mais vantajosa por ser mais rápida, apresentar menor custo, ser simples e ainda poder ser utilizada em qualquer laboratório com o mínimo de equipamentos de biologia molecular.

Outras PCRs descritas na literatura, porém não comparadas com as amostras deste trabalho, têm relatos de sensibilidade por volta de $10^{1,5} \mathrm{TCDI}_{50} \mathrm{~mL}^{-1}$ (LEE et al., 2007; PÉREZ \& ARCE, 2009), o que é 100 vezes menos sensível do que quando a reação é realizada pela metodologia com a etapa de nested padronizada neste trabalho. Além disso, outra nestedPCR, também baseada em gE, obteve acurácia de apenas $57,5 \%$ em cérebros de suínos (YOON, 2005). Os resultados de sensibilidade obtidos por esses autores 
são diferentes quando comparados aos deste trabalho, provavelmente em razão da região de amplificação da PCR, de reagentes utilizados ou do método de extração, características que geralmente alteram o desempenho da PCR (ESPY et al., 2006).

A nested-PCR descrita neste trabalho demonstrou ser confiável para o diagnóstico da PR, podendo ser utilizada como padrão na detecção do PrV. A técnica também pode ser útil como método auxiliar em programas de erradicação como método confirmatório em casos de animais únicos reativos, ou seja, indivíduos que sejam positivos no método de triagem (ELISA para glicoproteína B), porém negativos no ELISA para diferenciação de animais vacinados (BASCUNÃNA et al., 1997).

\section{CONCLUSÃO}

O método usual de genotipagem do PrV pode demorar até sete dias, já que o isolamento viral é necessário. Além da alta sensibilidade, detectando até $10^{-1,3}$ TCID $_{50} \mathrm{~mL}^{-1}$ de vírus nas amostras clínicas, o teste descrito foi relativamente mais rápido, com resultados em dois dias. O desenvolvimento dessa metodologia para diferenciação do PrV é muito relevante para estudos epidemiológicos, podendo desse modo identificar os fluxos de infecção nos rebanhos brasileiros, nos últimos surtos relatados, bem como estabelecer estratégias de prevenção de novos focos da doença.

\section{AGRADECIMENTOS}

Agradecimentos à FAPEMIG e ao LANAGRO/MGMAPA, pelo suporte financeiro ao trabalho, à EMBRAPA Suínos e Aves, ao CEDISA e ao IPVDF, pelo fornecimento das amostras clínicas.

\section{REFERÊNCIAS}

BANKS, M. DNA restriction fragment length polymorphism among british isolates of Aujeszky's disease virus: use of the polymerase chain reaction to discriminate among strains. British Veterinary Journal v.149, p.155-163, 1993.

BASCUÑANA, C.R. et al. Detection of pseudorabies virus genomic sequences in apparently uninfected "single reactor" pigs. Veterinary Microbiology v.55, p.37-47, 1997. Disponível em: $<\mathrm{ht} \mathrm{t}$ : / / w w w. s c i e n c edirect. c o m / science?_ob=ArticleURL\&_udi=B6TD6-3RJG23 M$5 \&$ _user $=4741058 \&$ rdoc $=1 \&$ fmt $=$ \&_orig $=$ search\&_sort $=\mathrm{d} \&$ _docanchor $=\&$ view $=$ c\&_search StrId $=1173676688 \&$ 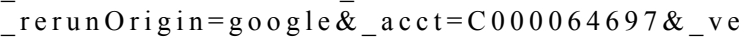 rs i o n $=1 \&$ \& ur 1 Version $=0 \&$ \& s e ri d $=47410$ $58 \& \mathrm{md} 5=317 \mathrm{a} \overline{7} 77 \mathrm{fa} 5 \mathrm{~b} 760 \mathrm{fba} 0 \mathrm{f} 8099597 \overline{7} 1 \mathrm{cad} 5>$. Acesso em: 10 mar. 2009. doi:10.1016/S0378-1135(96)01316-8.

BRASIL. Instrução Normativa 8 de três de abril de 2007. Aprova as Normas para o Controle e a Erradicação da Doença de
Aujeszky (DA) em suídeos domésticos, a serem observadas em todo o território nacional. Diário Oficial da União, Seção 1, Página 1, 10/04/2007.

CAULCUTT, R.; BODDY, R. Statistic for analytical chemists. Londres: Chapman and Hall, 1983. 256p.

CHRISTENSEN, L.S. et al. Restriction fragment pattern (FP) analysis of genomes from Danish isolates of suid herpesvirus 1 (Aujeszly's disease virus). Archives of Virology, v.97, p.215224, 1987. Disponível em: <http://www.springerlink.com/ content $/ \mathrm{m} 18 \mathrm{p} 338844442121 />$. Acesso em: 10 mar. 2009. d oi: $10.1007 / \mathrm{BF} 01314422$.

CHRISTENSEN, L.S. Comparison by restriction fragment pattern analysis and molecular characterization of some European isolates of suid herpesvirus 1: a contribution to strain differentiation of European isolates. Archives of Virology, v.102, p.39-47, 1988. Disponível em: <http:// www.springerlink.com/content/xh4j848x2488g212/>. Acesso em: 20 jan. 2010. doi: 10.1007/BF01315561.

CHRISTENSEN, L.S. et al. Characterization of field isolates of suid herpesvírus 1 (Aujeszky's disease virus) as derivates of attenuated vaccine strains. Archives of Virology v.124, p.225234, 1992. Disponível em: <www.springerlink.com/index/ P0R7V54G4456X8L6.pdf>. Acesso em: 21 jan. 2009. doi: 10.1007/BF01309804

CHRISTENSEN, L.S. Population biology of suid herpesvirus 1. APMIS, supl.48, p.1-48 1995.

ESPY, M.J. et al. Real-Time PCR in clinical microbiology: applications for routine laboratory testing. Clinical Microbiology Reviews, v.19, n.1, p.165-256, 2006. Disponível em: <http://cmr.asm.org/cgi/content/abstract/19/1/165>. Acesso em: 15 mar. 2009. doi: 10.1128/CMR.00022-06.

FONSECA Jr., A.A. et al. Molecular epidemiology of Brazilian pseudorabies viral isolates. Veterinary Microbiology, 2009. Online. Obtido via base de dados Pubmed. Disponível em: $<\mathrm{ht} \mathrm{t}$ p: / / w w w s c i e n c e d i r e c t c o m / science?_ob=ArticleURL\&_udi=B6TD6-4X9NV5N$5 \&$ \& us e r $=4741058 \&$ r d oc $=1 \&$ \& f t $=\&$ _orig $=$ s e arch\&_sort $=$ d \&_d oc ancho $\bar{r}=\&$ vi e $\bar{w}=c \&$ 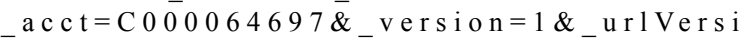 on $=0 \&$ userid $=4741058 \& \mathrm{md} 5=\mathrm{e} 96 \overline{6} \mathrm{ab} 7267 \mathrm{f} 869 \mathrm{fe} 988 \mathrm{bab} 633 \mathrm{f} 905743 \mathrm{e}>$. Acesso em: 25 set. 2009. doi:10.1016/j.vetmic.2009.09.018 .

GART, J.J.; BUCK, A.A. Comparison of a screening test and a reference test in a epidemiologic studies. American Journal of Epidemiology, v.83, n.1, p.593-602, 1966. Disponível em: <http://aje.oxfordjournals.org/cgi/pdf_extract/83/3/593>. Acesso em: 08 jan. 2009.

GOLDBERG, T.L. Application of phylogeny reconstruction and character-evolution analysis to inferring patterns of directional microbial transmission. Preventive Veterinary Medicine v.61, n.59-70, 2003. Disponível email: $<$ http// linkinghub.elsevier.com/ retrieve/pii/S0167587703001612>. Acesso em: 10 mar. 2009. doi:10.1016/S0167-5877(03)00161-2

KJELD, O. 2006. Pdraw32. Disponível em: http:// www.acaclone.com/. On line. Acesso em: 10 jan. 2009. 
KLUGE, J.P. et al. Pseudorabies (Aujeszk's disease). In: STRAW, B.E. et al. (eds). Diseases of swine. 8.ed. Ames, Iowa: Iowa State University, 1999. p.147-160.

LEE, C. S. et al. Multiplex PCR for the simultaneous detection of pseudorabies virus, porcine cytomegalovirus, and porcine circovirus in pigs. Journal of Virological Methods, v.139, n.1, p.39-43, 2007. Disponível em: <http://linkinghub.elsevier.com/retrieve/ pii/S0166093406003132>. Acesso em: 29 mar. 2009. doi:10.1016/ j.jviromet.2006.09.003

METTENLEITER, T.C. Aujeszky's disease (pseudorabies) virus: the virus and molecular pathogenesis - state of the art, june 1999 Veterinary Research v.31, p.99-115, 2000. Disponível em: $<$ http:// linkinghub.elsevier.com/retrieve/pii/S0166093406003132>. Acesso em: 20 jan. 2010. doi:10.1016/j.jviromet.2006.09.003.

MURPHY, F.A. et al. Virus Taxonomy. Classification and nomenclature of viruses. Sixth report of the international Commitee on Taxonomy of Viruses. Archives of Virology v.10, p.120-121,1995. Disponível em: <http:// www.springerlink.com/content/rm81150778g49n11/>. Acesso em: 20 jan. 2010. doi: 10.1007/BF01309873

NISHIMORI, T. et al. Restriction endonuclease analysis of Aujeszky's disease viruses isolated in Japan. Japonese Journal of Veterinary Science v.49, n.2, p.365-367, 1987.

OIE, World Organization for Animal Health. Manual of diagnostic tests and vaccinesfor terrestrial animal. 6.ed. Paris, 2008. 1343p. Disponível em: <http://www.oie.int/eng/ normes/mmanual/A_summry.htm>. Acesso em: 19 jan. 2010

PEREZ, L.J.,;HEIDY, H.D. Development of a polymerase chain reaction assay for the detection of pseudorabies virus in clinical samples. Brazilian Journal of Microbiology v.40, n.3, p.433-438, 2009. Disponível em: <http://www.scielo.br/ s c i elo.ph p s c ri pt=s ci art text \& pid $=$ S 1517 $83822009000300002 \& \operatorname{lng}=$ en\&nrm=iso\&tlng=en $>$. Acesso em: 28 out. 2009 . doi: $10.1590 / \mathrm{S} 1517-83822009000300002$

PIATTI, R.M. et al. Characterization of Aujeszky's disease virus isolates from south and southeast Brazil by RFLP analysis. Brazilian Journal of Microbiology v.32, p.144-146, 2001. Disponível em: <http://www.scielo.br/scielo.php?pid=S1517$83822001000200015 \&$ script $=$ sci arttext $>$. Acesso em: 10 mar. 2009. doi: 10.1590/S1517-83822001000200015.

POMERANZ et al. Molecular biology of pseudorabies virus: impact on neurovirology and veterinary medicine. Microbiology Molecular Biology Reviews v.69, n.3, p. $462-$ 500, 2005. Disponível em: $<$ http//:mmbr.asm.org/cgi/content/ abstract/69/3/462>. Acesso em: 21 mar. 2009. doi:10.1128/ MMBR.69.3.462-500.2005

ROZEN, S.; SKALETSKY, H.J. Primer3. Code available at http://www.bioinformatics.nl/cgi-bin/primer3plus/ primer3plus.cgi. Acesso em: 12 dez. 2008

SÁMI, L. et al. Simultaneous detection of three porcine viruses by multiplex PCR. Acta Veterinaria Hungarian, v. 55, n 2, 267-276, 2007. Disponível em: <linkinghub.elsevier.com/ retrieve/pii/S0166093406003132>. Acesso em: 16 jun. 2009. doi:10.1016/j.jviromet.2006.09.003

SILVA, A.D. et al. Caracterização antigênica e molecular de oito amostras do vírus da doença de Aujeszky isoladas no estado do Rio Grande do Sul em 2003. Pesquisa Veterinária Brasileira v.25, n.1, p.21-24, 2005. Disponível em: <http:/ /www.scielo.br/pdf/bjm/v37n3/v37n3a35.pdf>. Acesso em: 08 jan. 2009. doi: 10.1590/S0100-736X2005000100005.

SCHAEFER, R. et al. Characterization of Aujeszky's disease virus isolated from South Brazil in the last twenty years by restriction enzyme analysis. Brazilian Journal of Microbiology v.37, n.3, p.390-394, 2006. Disponível em: $<$ http://www.scielo.br/pdf/bjm/v37n3/v37n3a35.pdf $>$. Acesso em: 17 set. 2008 . doi: $10.1590 / \mathrm{S} 1517-83822006000300035$.

YAMADA, S. et al. Characterization of Japanese isolates of Aujeszky's disease virus by restriction endonuclease cleavage patterns, virulence in mice and thymidine kinase activity. Journal of Veterinary Medical Science, v.54, n.3, p.541549, 1992. Disponível em: <http://www.journalarchive.jst.go.jp/ jn l pdf.php? cdjournal=jvms $1991 \&$ cdvol $=54$ \&noissue $=3$ \&startpage $=523$ \&lang $=$ en $\&$ from $=$ jnltoc. Acesso em: 20 jan. 2010. doi: não informado.

YOON, H.A. et al. Molecular survey of latent pseudorabies virus infection in nervous tissues of slaughtered pigs by nested and real-time PCR. Journal of Microbiology, v.43, n.5, p.430-436, 2005. Disponível em: <http://www.msk.or.kr/jsp/ view_old_journalD.jsp?paperSeq=2279>. Acesso em: 14 mai. 2009. doi: não informado.

YOON, H.A. et al. Investigation of pseudorabies virus latency in nervous tissues of seropositive pigs exposed to field strain. Journal of Veterinary Medical Science, v.68, n.2, p.143148, 2006. Disponível em: <http://www.jstage.jst.go.jp/ article/jvms/68/2/68 143/article $>$. Acesso em: 14 mai. 2009.

WEIGEL, R.M.; SCHERBA, G. Quantitative assessment of genomic similarity from restriction fragment patterns. Preventive Veterinay Medicine, v.32, p.95-110, 1997. Disponível em: <http://linkinghub.elsevier.com/retrieve/pii/ S0167587796011348>. Acesso em: 14 mai. 2009. doi:10.1016/ S0167-5877(96)01134-8. 